\title{
Phosphorus Sorption by Gravels in Lateritic Soils
}

\author{
D. M. Weaver, G. S. P. Ritchie and R. J. Gilkes
}

\begin{abstract}
The effect of sesquioxidic gravels (>2 mm size fraction) on phosphorus sorption by two gravelly lateritic soils was investigated by phosphorus sorption experiments, X-ray diffraction, autoradiography and electron microscopy.

In one soil the abundance and size of gravels decreased downslope. As the gravel content of both soils increased (13-61\%), the proportion of large $(>8 \mathrm{~mm})$ gravels increased $(0-70 \%)$. Phosphorus sorption increased in the order: $(>2 \mathrm{~mm}$ fraction) $<$ (whole soils) $<(<2 \mathrm{~mm}$ fraction). Phosphorus sorption on lateritic gravels ( $>2 \mathrm{~mm}$ ) decreased with increasing gravel size and increased with increasing time. Phosphorus sorption by whole soils decreased with increasing gravel content. Phosphorus sorption by the $>2 \mathrm{~mm}$ fraction was principally by the external surfaces of the gravels. The estimation of phosphorus application rates for lateritic soils depended on the amount of phosphorus required by the plant and the gravel content of the soil. The former is the important factor at low soil gravel contents whereas the latter becomes more important as the gravel content increases. The implications for fertilizer management on the soil with consistent relationships between landscape position, gravel content and subsequent $\mathrm{P}$ sorption properties of whole soils are discussed.
\end{abstract}

Keywords: phosphorus, sorption, gravel, laterite.

\section{Introduction}

The extensive use of lateritic soils for crop and pasture production in south Western Australia has required much research into improving their poor nutritional status. Particular emphasis has been paid to the reactions of phosphorus $(P)$ with the soil so that the availability of applied $\mathrm{P}$ for plant growth may be predicted more accurately (Khasawneh et al. 1980). Lateritic soils contain various amounts of sesquioxidic gravels (>2 mm fraction of the soil) which differ in their size, mineralogical composition and distribution throughout the landscape and soil profile. Phosphorus may be associated with iron in ferruginous concretions (Taylor and Schwertmann 1974), however, the relative contribution of iron oxide containing gravels to the sorption of $\mathrm{P}$ by soils is not known. This process could be significant in soils with abundant gravel in the topsoil. Most procedures for determining the capacity of a soil to sorb $P$ involve measuring sorption by the $<2 \mathrm{~mm}$ fraction (fine earth) of the soil. Similarly, most soil tests for available plant nutrients use the $<2 \mathrm{~mm}$ fraction of soils, and glasshouse experiments determining nutrient requirements of plants commonly use the $<4 \mathrm{~mm}$ fraction. 
The use of gravel free soil for analysis is appropriate when the $>2 \mathrm{~mm}$ fraction is composed of relatively inert primary minerals (e.g. quartz, feldspar) or when the $>2 \mathrm{~mm}$ fraction is a small percentage of the whole soil. Lateritic gravels, however, contain chemically reactive minerals (e.g. iron and aluminium oxides) that could contribute to soil chemical reactions and influence the availability to plants of some nutrients. Consequently, use of the $<2 \mathrm{~mm}$ fraction for analysis could be misleading when reactive gravels $(>2 \mathrm{~mm})$ that sorb $\mathrm{P}$ are a major constituent of the soil. This study was undertaken to investigate the effect of the amount, size distribution, landscape position, surface morphology and mineralogy of gravels on the sorption of $\mathrm{P}$ by lateritic soils.

\section{Materials and Methods}

\section{Soils}

The soils were sampled from sites at Bakers Hill, Western Australia. Detailed profile descriptions of typical laterites at the locality together with mineralogical and chemical characteristics are given by Gilkes et al. (1973). The region is mostly mantled by complete laterite profiles (e.g. the Yalanbee soil) and soils developed on colluvial materials derived from erosion of lateritic soils. Soils on valley sides (e.g. the Malebelling soil) have developed from mixtures of granitic and lateritic colluvium, including lateritic gravels (Mulcahy 1960). Gravels in the Yalanbee soils are predominantly of lateritic origin, those in the Malebelling soil include lateritic colluvium but also include gravels that have formed in situ. Both soils are common in agricultural regions of Western Australia.

Samples from each of the $0-15$ and $15-30 \mathrm{~cm}$ layers of the Yalanbee soil were collected at four sites down a uniform slope of about $4^{\circ}$ at approximately $100 \mathrm{~m}$ intervals (Table 1; sample A, upslope; sample B, upper-midslope; sample C, lower-midslope; sample D, downslope). Samples from each of the $0-15$ and $15-30 \mathrm{~cm}$ layers of the Malebelling soil were collected at nine sites from two transects (four samples in one transect and five in the other) with uniform slopes of $4^{\circ}$.

\section{Abundance and Size of Gravels}

The particle size distribution for each sample was determined by sieving a subsample in nests of $8,5 \cdot 6,4,2 \cdot 8$ and $2 \mathrm{~mm}$ mesh stainless steel sieves using a mechanical shaker. This produced five gravel fractions $(2 \cdot 0-2 \cdot 8,2 \cdot 8-4 \cdot 0,4 \cdot 0-5 \cdot 6,5 \cdot 6-8 \cdot 0$ and $>8 \cdot 0 \mathrm{~mm})$ and a fine earth $(<2 \mathrm{~mm})$ fraction. Data collected from samples in which the soil gravel content varied by less than $1 \%$ were averaged.

The gravels were cleaned of adhering matrix materials by ultrasonic treatment in deionized water for $10 \mathrm{~min}$ and then dried at $60^{\circ} \mathrm{C}$.

\section{Mineralogy of Soil Materials}

Subsamples of the $<2 \mathrm{~mm}$ and $>2 \mathrm{~mm}$ fractions were finely ground in a Tema mill and the major minerals were determined by X-ray diffraction (Gilkes et al. 1973).

\section{Sorption of $P$ by Soil Materials}

Four surface samples $(0-15 \mathrm{~cm})$ with similar mineralogical composition but with differing amounts and size distributions of gravel (Yalanbee A-D, Table 1) and one surface sample $(0-15 \mathrm{~cm})$ that was mineralogically different but with a similar amount and size distribution of gravel to one of the Yalanbee samples (Malabelling E, Table 1) were chosen for P sorption studies.

The phosphorus sorbed by the $<2 \mathrm{~mm}$ fraction (fine earth), $>2 \mathrm{~mm}$ fraction (gravel) and the whole soil (i.e. the fine earth and gravel components reconstituted to the soils original composition) was determined for the samples listed in Table 1 by incubating each sample quiescently with $0,10,40,160$ and $400 \mathrm{mg} \mathrm{P} / \mathrm{L}$ at ambient temperature and a solid: solution 
Table 1. Characteristics related to phosphorus sorption

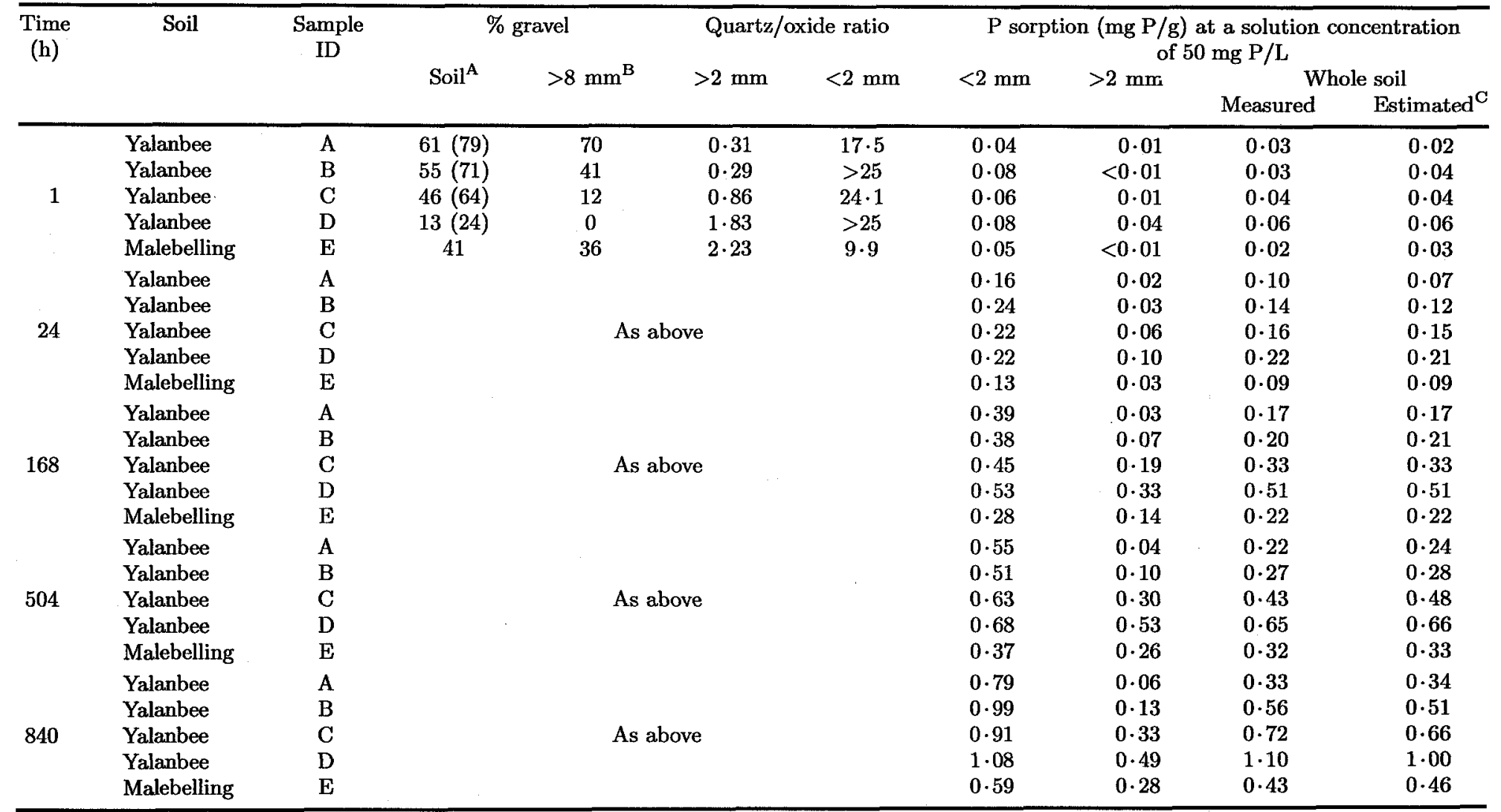

A Percentage of gravels in the surface soil $(0-15 \mathrm{~cm})$. Values in parentheses show the percentage of gravel in the subsurface soil (15-30 cm).

B Percentage of gravel fraction that is $>8 \mathrm{~mm}$.

C Calculated by adding the contribution of the $>2 \mathrm{~mm}$ and $<2 \mathrm{~mm}$ fractions to sorption in the measured proportions per gram of whole soil. 
(a)

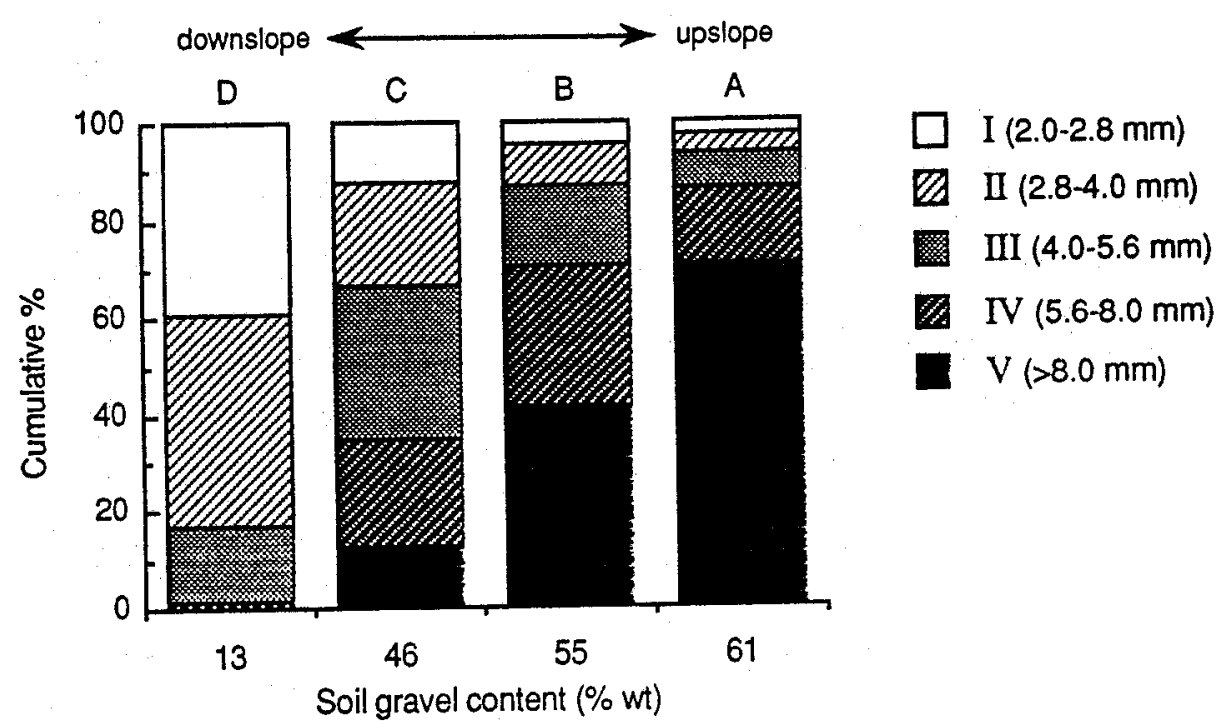

(b)

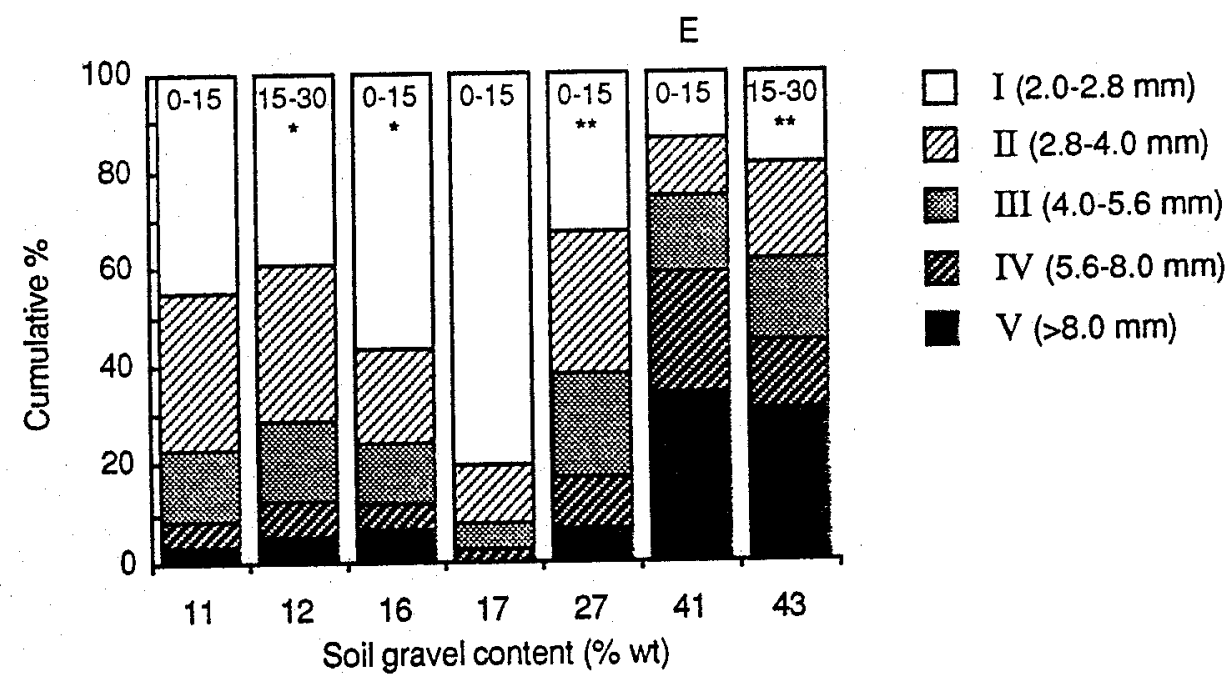

Fig. 1. Gravel size distribution (cumulative \%) at different soil gravel contents for the (a) Yalanbee $(0-15 \mathrm{~cm})$ and $(b)$ Malebelling $(0-15 \mathrm{~cm}$ and $15-30 \mathrm{~cm}$ identified on each bar with * and ${ }^{* *}$ respectively indicating samples from each depth at the same site) soils for gravels $2 \cdot 0-2 \cdot 8$ (I), $2 \cdot 8-4 \cdot 0$ (II), $4 \cdot 0-5 \cdot 6$ (III), 5.6-8.0 (IV), and $>8 \cdot 0 \mathrm{~mm}$ (V). Letters identify samples used in sorption experiments (Table 1). 
ratio of $1: 5$. Phosphorus remaining in solution after $1 \mathrm{~h}, 1,7,21$ and 35 days was determined colorimetrically (Hanson 1950). Phosphorus sorption isotherms were determined using the Freundlich equation and the amount of $\mathrm{P}$ sorbed at a solution $\mathrm{P}$ concentration of $50 \mathrm{mg} \mathrm{P} / \mathrm{L}$ was derived. Analysis of variance was used to determine the significance of differences between the amount of $\mathrm{P}$ sorbed by different fractions, soils and times. Least significant differences were determined for each comparison made.

\section{Phosphorus Penetration into Gravels}

Yalanbee and Malebelling gravels of relatively uniform size were selected to assess the extent of $P$ penetration in gravels. A uniform size was required to ensure that the qualitative assessment of the distribution of the sorbed $P$ was based upon the uniformity of darkening of the film and the thickness of the gravel sample. This made it possible to distinguish more clearly between darkening of the film due to sorbed $P$ at a particular site and darkening which was an artifact of scattered radiation and radiation penetrating the sample.

Samples of $2 \cdot 0-2 \cdot 8$ and $5 \cdot 6-8 \cdot 0 \mathrm{~mm}$ Yalanbee gravels and 5.6-8.0 mm Malebelling gravels were incubated with 50 and $1000 \mu \mathrm{g}$ of ${ }^{31} \mathrm{P} / \mathrm{g}$ gravel with 1.5 and $1 \mu \mathrm{Ci}$ of ${ }^{32} \mathrm{P} / \mathrm{g}$ gravel for $24 \mathrm{~h}$ and 1 week. After this period, the gravels were washed in deionized water, dried at $60^{\circ} \mathrm{C}$ and impregnated under vacuum with Araldite resin. The impregnated samples were sectioned and polished and autoradiographs were produced by dry contact between the polished section and Osray RR-1 X-ray film for $3 \mathrm{~h}$.

\section{Surface Morphology of Gravels}

The fabric of Yalanbee and Malebelling gravels was assessed qualitatively by scanning electron microscopy of random sections of external and fractured internal surfaces.

\section{Results}

\section{Abundance and Size of Gravels}

Gravels occured in each of the Yalanbee sites at the two sampling depths. Not all of the sampled sites of the Malebelling soil contained gravel. Of the nine surface $(0-15 \mathrm{~cm})$ samples of the Malebelling soil, six contained gravel, and of the nine subsurface $(15-30 \mathrm{~cm})$ samples two contained gravel. Two of the Malebelling surface $(0-15 \mathrm{~cm})$ samples contained the same amount of gravel and very similar size distributions and these data were averaged to represent one sample.

As the gravel content of the Yalanbee and Malebelling soils increased, the proportion of the gravels in the larger size fraction $(>8 \mathrm{~mm})$ increased and the proportion of gravels in the smaller size fraction $(2 \cdot 0-2 \cdot 8 \mathrm{~mm})$ decreased (Figs $1 a$ and $1 b$ ). Relationships between soil gravel content $(x)$ and the percentage of gravel $>8 \mathrm{~mm}(y)$ were

$$
y=10 \cdot 3+0.95 x \quad(R=0.92, P<0.05)
$$

and

$$
\log (1+y)=-0.53+0.038 x \quad(R=0.99, \quad P<0.05)
$$

for the Malebelling and Yalanbee soils respectively. Relationships between soil gravel content $(x)$ and the percentage of gravel $2 \cdot 0-2 \cdot 8 \mathrm{~mm}(y)$ were

$$
y=70.4-1.24 x \quad(R=0.73, P<0.1)
$$

and

$$
y=49 \cdot 1-0 \cdot 79 x \quad(R=0.99, P<0.05)
$$


for the Malebelling and Yalanbee soils respectively.

In the Yalanbee soil, both the size and abundance of gravels were related to landscape position. The gravel content and the proportion of gravels in the larger size fractions of the Yalanbee soil were highest upslope (sample A; $61 \%$ gravel content, $70 \%$ greater than $8 \mathrm{~mm}$ ) and graded to a low content of gravel (sample $\mathrm{D} ; 13 \%$ ) with a low proportion of gravel (sample $\mathrm{D} ; 0 \%$ ) in the larger size fractions (Table 1). The gravel content of the subsurface layers was greater than the gravel content of the surface layers by $11-18 \%$ (Table 1) and the relationships of size and abundance of gravels were similarly related to landscape position (data not shown).

In the Malebelling soil there was no relationship to landscape position.

\section{Mineralogy of Soil Materials}

Quartz and kaolinite were the major components of the $>2 \mathrm{~mm}$ and $<2 \mathrm{~mm}$ fractions of the soils. The quartz/oxide ratio indicated that the $>2 \mathrm{~mm}$ fraction contained larger amounts of iron and aluminium minerals than the $<2 \mathrm{~mm}$ fraction (Table 1). Gibbsite and boehmite were the major hydrous oxides present in the Yalanbee soil, whereas they were almost absent in the Malebelling soil. In the Malebelling gravels, goethite was the major iron mineral with small amounts of haematite also being present.

\section{Sorption of $P$ by Soil Materials}

The P sorption capacities of the different fractions of the Yalanbee and Malebelling soils were mostly in the order: ( $<2 \mathrm{~mm}$ fraction) $>$ whole soil $>(>2 \mathrm{~mm}$ fraction) and this effect was significant at $P<0.05$ (l.s.d. 0.03). The $P$ sorption capacity of the $<2 \mathrm{~mm}$ soil fractions followed the order: Yalanbee $>$ Malebelling (Table 1) and this effect was significant at $P<0.05$ (l.s.d. 0.15). The order was the same for whole soils regardless of whether the $P$ sorbed was measured or estimated (by adding the contribution of the $>2 \mathrm{~mm}$ and $<2 \mathrm{~mm}$ fractions in the measured proportions per gram of whole soils), with values obtained by the two procedures being not significantly different (Table 1). Phosphorus sorption increased significantly $(P<0.05)$ from sample A (upslope) to sample $\mathrm{D}$ (downslope) for the $<2 \mathrm{~mm}$ fraction (l.s.d. 0.08), $>2 \mathrm{~mm}$ fraction (l.s.d. 0.13) and whole Yalanbee soils (l.s.d. 0.17).

At a constant level of $\mathrm{P}$ remaining in solution, the amount of $\mathrm{P}$ sorbed by the Yalanbee whole soil decreased as the proportion of gravel in the whole soil increased (Fig. 2a). As the gravel content of mineralogically similar soils (e.g. Yalanbee soils) increased, the difference in sorption between the $<2 \mathrm{~mm}$ fraction and the whole soil became greater (Fig. $2 a$ ). At relatively low soil gravel contents (13\%), $\mathrm{P}$ sorption by the whole soil and the corresponding $<2 \mathrm{~mm}$ fraction was similar.

The $P$ sorption capacity of the $>2 \mathrm{~mm}$ fractions of the soils depended on their size distribution and mineralogical composition. At a constant level of $P$ remaining in solution, the amount of $P$ sorbed by the $>2 \mathrm{~mm}$ fraction of the Yalanbee soil increased as the proportion of larger gravels in the $>2 \mathrm{~mm}$ fraction decreased (Fig. $2 b$ ). The $\mathrm{P}$ sorption capacity of the Yalanbee $>2 \mathrm{~mm}$ fraction increased as the proportion of $>8 \mathrm{~mm}$ gravels in the $>2 \mathrm{~mm}$ fraction decreased 
(Fig. $2 b$ ) from upslope (sample A) to downslope (sample D). The difference in $\mathrm{P}$ sorption capacity of mineralogically different gravels of a similar size distribution (samples $\mathrm{C}$ and $\mathrm{E}$ ) was small but significant $(P<0.05$, l.s.d.0.03).

(a)

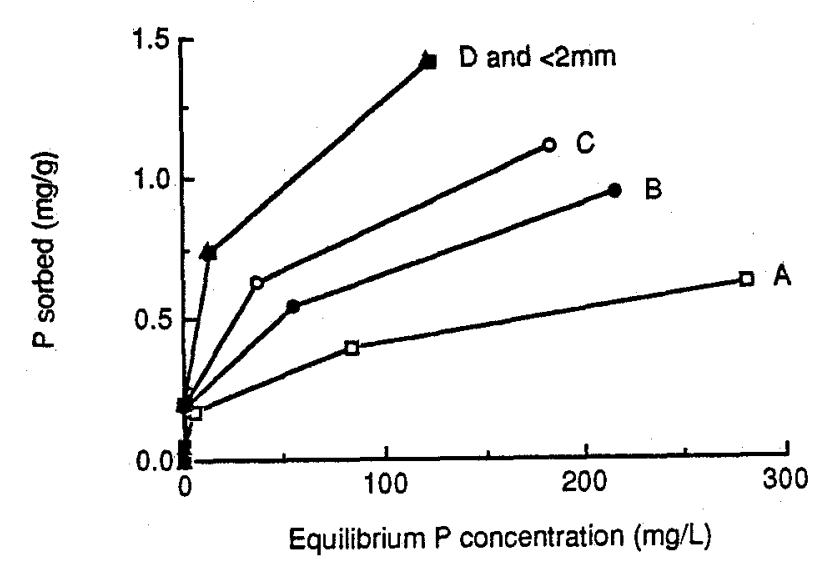

(b)

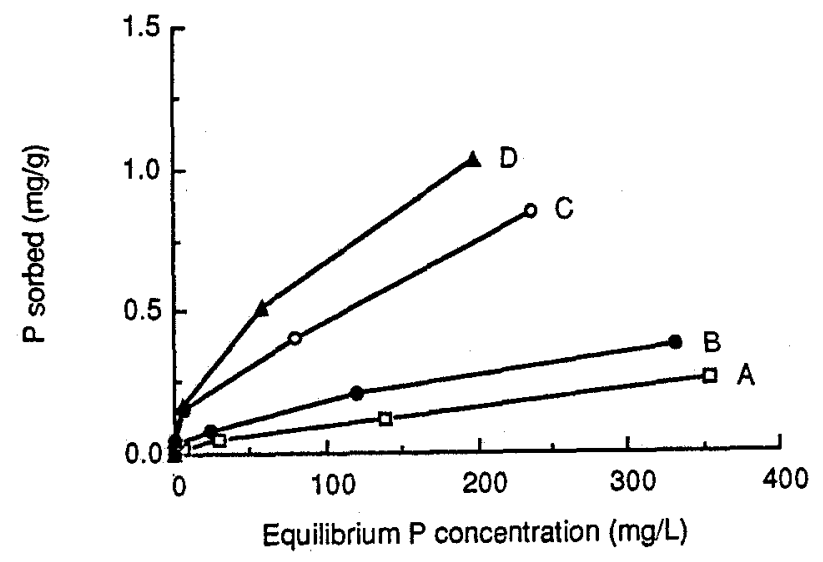

Fig. 2. $\mathrm{P}$ sorbed $(\mathrm{mg} / \mathrm{g})$ after 5 weeks as a function of equilibrium $\mathrm{P}$ concentration for $(a)$ Yalanbee whole soil containing gravel contents of $13 \%$ (sample D, A), $46 \%$ (sample C, O),

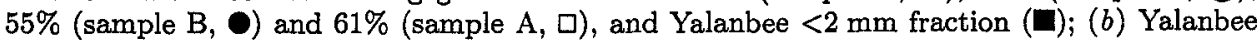
gravels containing $>8 \mathrm{~mm}$ gravel contents of $0 \%$ (sample $\mathrm{D}, \boldsymbol{\Lambda}$ ), $12 \%$ (sample $\mathrm{C}, \mathrm{O}$ ), $41 \%$ (sample B, ) and $70 \%$ (sample A, 口).

Phosphorus sorption increased with time $(P<0.05$, l.s.d. 0.04$)$ for the $<2 \mathrm{~mm}$ fraction, $>2 \mathrm{~mm}$ fraction and whole soils for both Yalanbee and Malebelling soils (Table 1). Similar trends with gravel size or soil gravel content to those already stated were observed at each time for the Yalanbee soil. The greatest difference in $\mathrm{P}$ sorption with increasing time was for the $<2 \mathrm{~mm}$ fraction of Yalanbee and Malebelling soils. The least difference in $\mathrm{P}$ sorption with increasing time was for the $>2 \mathrm{~mm}$ fraction of the Yalanbee and Malebelling soils and the extent of the 
(a)

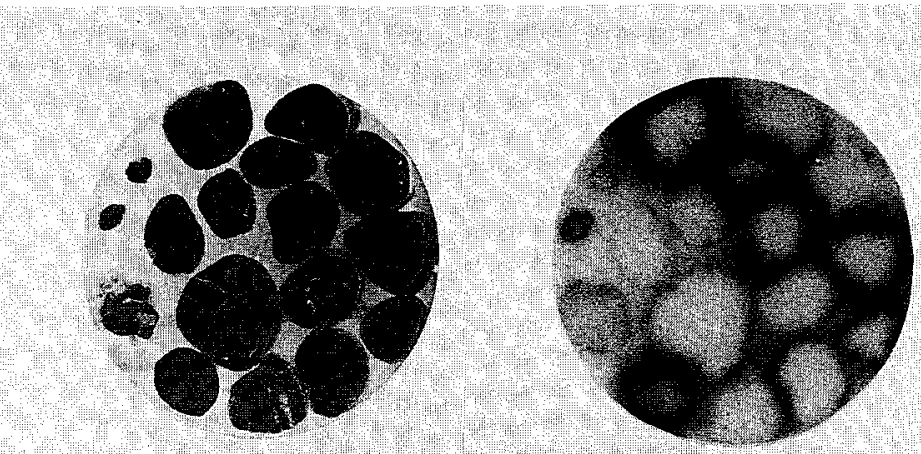

(b)

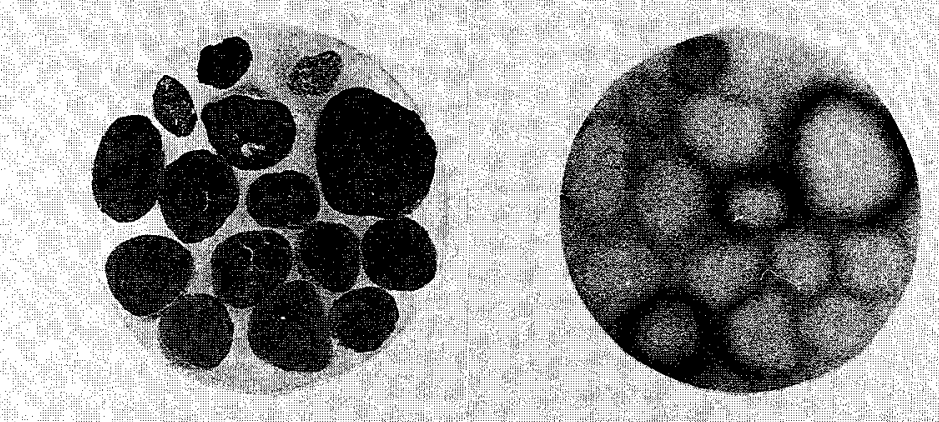

(c)
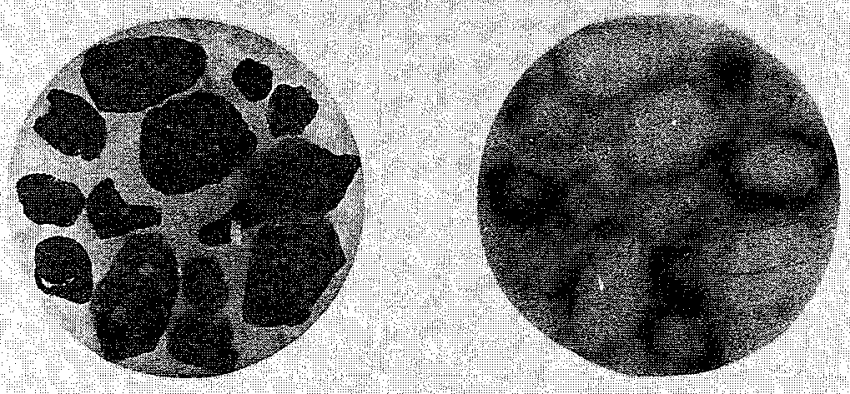

(d)

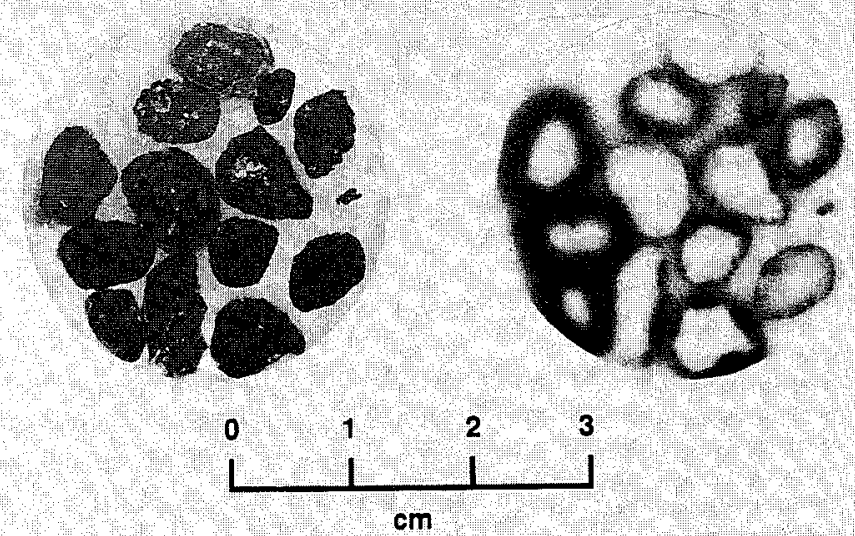

Fig. 3. Autoradiographs (right hand side; sectioned samples left hand side) for the Yalanbee $(a, b)$ and Malebelling $(c, d)$ gravels after $24 \mathrm{~h}(a, c)$ and 1 week $(b, d)$ sorption period. 
difference was greatest when the percentage of gravels $>8 \mathrm{~mm}$ in the Yalanbee soil was low (sample D, 0\%). The difference in $\mathrm{P}$ sorption with increasing time for the whole Yalanbee soils was greatest for soils with low gravel contents (sample D, $13 \%$ ) and least for whole Yalanbee soils with high gravel contents (sample A, $61 \%$ ). At each time, whole Yalanbee soils with low gravel contents (sample D, $13 \%$ ) sorbed similar amounts of $\mathrm{P}$ to the corresponding $<2 \mathrm{~mm}$ fraction (Table 1 ).

\section{Phosphorus Penetration into Gravels}

Qualitative assessment of the autoradiographs showed that $\mathrm{P}$ had not penetrated beyond the surface of any of the gravels after one week (Fig. 3) except when there was a crack in the gravel (Fig. $3 b$ ). In this case the $\mathrm{P}$ appeared to be sorbed in the region immediately adjacent to the crack. There were no differences in the extent of $\mathrm{P}$ penetration after one week for the sizes of gravel assessed (data for $2 \cdot 0-2 \cdot 8 \mathrm{~mm}$ Yalanbee gravels not shown) or the amount of $\mathrm{P}$ applied.
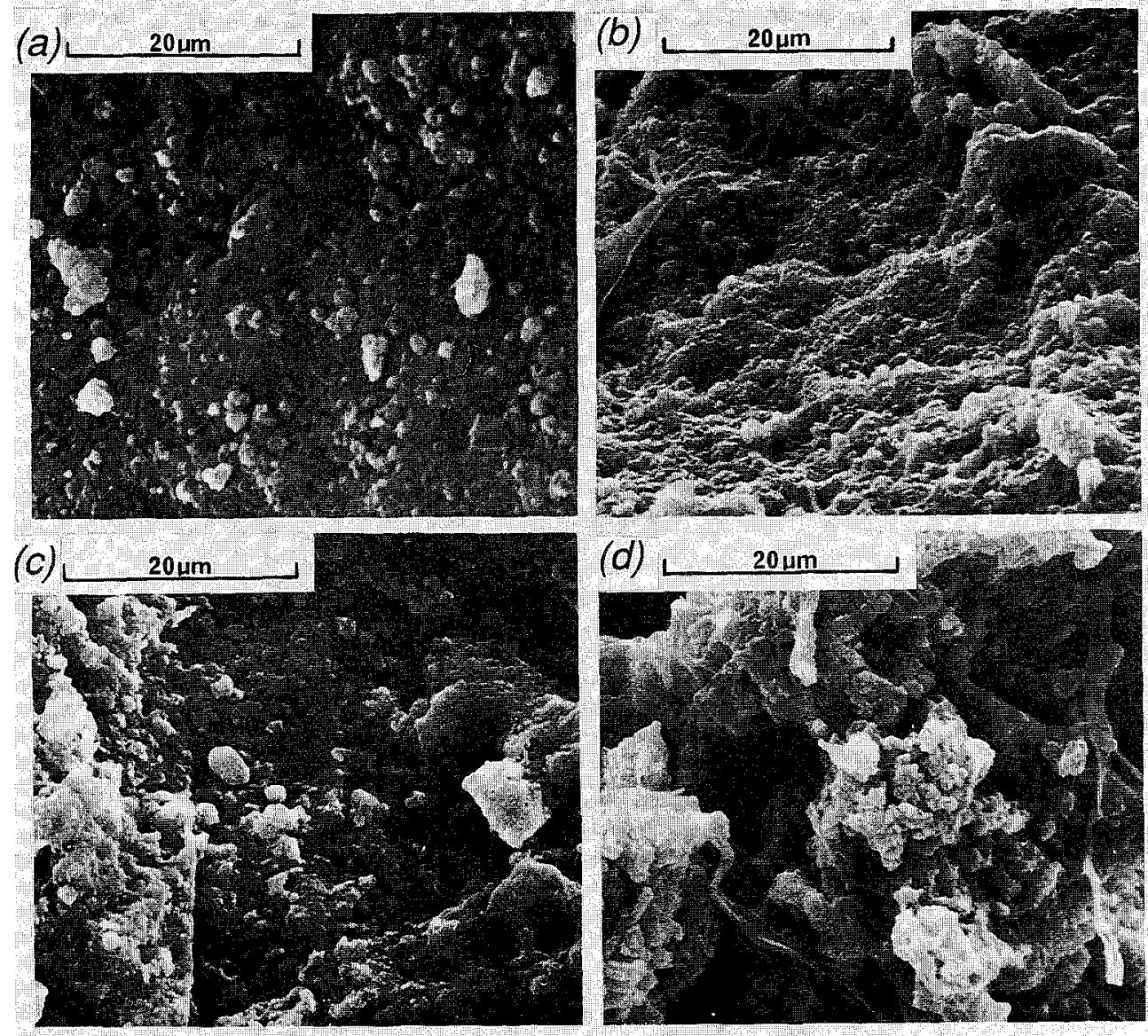

Fig. 4. Scanning electron micrographs of the exterior $(a, b)$ and interior $(c, d)$ surfaces of Yalanbee $(a, c)$ and Malebelling $(b, d)$ gravels. 


\section{Surface Morphology of Gravels}

Comparison of scanning electron micrographs of the exterior of the two gravel types indicates that the Yalanbee gravels have a much smoother, more densely packed surface (Fig. 4a) than the Malebelling gravels (Fig. 4b). The Malebelling (Fig. $4 b$ ) gravels have a much coarser surface texture and greater variability of fabric within the surface. The interior fracture surfaces of the gravels exhibit textures similar to the exterior surfaces (Fig. $4 c, d$ ).

\section{Discussion}

The amount of gravel and its size, surface characteristics and mineralogy may influence the contribution of gravels $(>2 \mathrm{~mm})$ to $\mathrm{P}$ sorption by lateritic soils.

The amount of gravel in one soil (Yalanbee) was related to its position in the landscape, with greater quantities of gravel of which most was of larger size (>8 mm) being found upslope, and smaller quantities of gravel of which most was of smaller size $(2 \cdot 0-4 \cdot 0 \mathrm{~mm})$ being found downslope. This feature of gradation in size and abundance downslope has been recognized previously by Finkl (1971) and Mulcahy (1960) and suggests that the lateritic material is secondary. Gilkes et al. (1973) also described gravels in these soils as having simple concentric layers, suggesting colluvial processes are in action. Gravel size and abundance in the Malebelling soil showed no relationship to landscape position, suggesting that these gravels may have formed in situ. In both soils, the amount of larger gravels $(>8 \mathrm{~mm}$ ) increased as the soil gravel content increased and the amount of smaller gravels $(2 \cdot 0-4.0 \mathrm{~mm})$ increased as the soil gravel content decreased.

Phosphorus sorption was dependent on the surface area of grains available for sorption since sorption was greatest for the $<2 \mathrm{~mm}$ fraction and least for the $>2 \mathrm{~mm}$ fraction. The size of the gravels appeared to influence the continuation of $\mathrm{P}$ sorption more than the amount of reactive minerals present. It appears that the larger surface area of the $<2 \mathrm{~mm}$ fraction was the controlling factor of the $\mathrm{P}$ reactions. The smaller size of particles exposed in the external surface of Yalanbee gravels could be responsible for their high sorption capacity in comparison with the Malebelling gravels. However, differences in surface characteristics of the gravels were insufficient to allow differences in penetration of $\mathrm{P}$ into the gravels. It is likely that the very slow movement of $\mathrm{P}$ through pores was the overriding factor in controlling its penetration into the interior of the gravel.

The significance of these findings arise through their implications for fertilizer application to Yalanbee soil for optimum pasture and crop production, but not for the Malebelling soil. A simple approach may be applied to sampling, soil testing and fertilization of the Yalanbee soil because of the relationship between landscape position, gravel content and subsequent $\mathrm{P}$ sorption properties of whole soils. It may be necessary, in order to avoid the increasing detrimental effects of nutrient runoff on water quality, to adopt a more rigorous approach (not necessarily as rigorous as the sampling protocol used in this study) to $\mathrm{P}$ fertilizer management in these soil types. For example, fertilization of the upper and lower sections of slopes at different rates may be feasible and acceptable from an economic and environmental viewpoint. In the Malebelling soil, the gravel content varied inconsistently with landscape position, and hence it would not be simple to soil test and fertilize paddocks according to landscape position (or gravel content). 
In a glasshouse experiment, clover and wheat required 400 and $170 \mu \mathrm{g} \mathrm{P} / \mathrm{g}$ soil respectively for optimum growth on the $<2 \mathrm{~mm}$ fraction of Yalanbee soil (Robson and Gilkes 1981). Phosphorus concentrations in solution associated with the above application rates may be calculated from the sorption isotherm of the $<2 \mathrm{~mm}$ fraction of Yalanbee soil. The sorption isotherm of the whole soil may then be used to estimate the application rate required to maintain the same $P$ solution concentrations in whole soils (the calculations were based on the five week sorption isotherms). This estimation assumes that the soil is stable and sorption is not affected by the soil: solution ratio (Barrow and Shaw 1979). It also assumes that $P$ solution concentrations calculated in this manner may be used as an indicator of plant response.

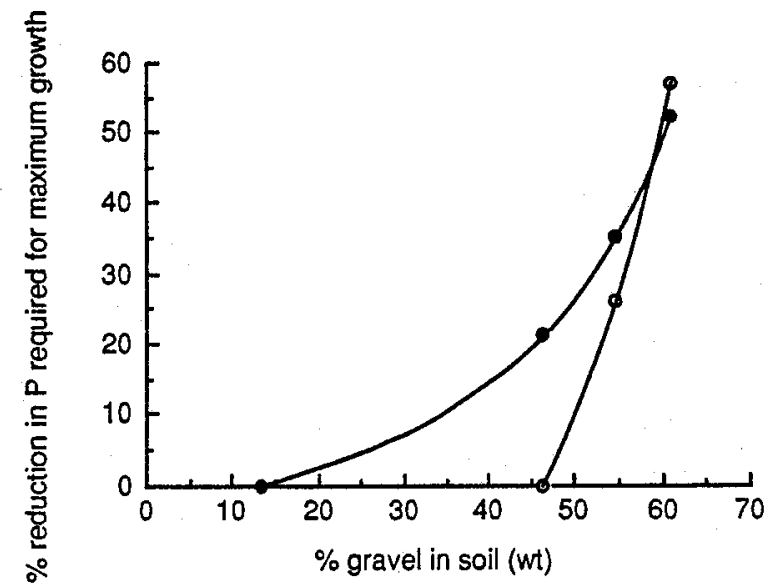

Fig. 5. Estimated reduction in $\mathrm{P}$ required for maximum growth of clover $(\bullet)$ and wheat (O) on Yalanbee soil at different soil gravel contents.

The estimated percentage decrease in application rates of $\mathrm{P}$ required for optimum growth decreased as the gravel content of the soil increased (Fig. 5). The decrease in $\mathrm{P}$ required differed for the two plant species because the extent of sorption (and therefore $P$ availability) is affected by two factors: the difference in sorption between the $<2 \mathrm{~mm}$ fraction and whole soil increases with increasing gravel content and it also increases with the amount of $P$ applied (see Fig. 2). Consequently, for plants with higher $\mathrm{P}$ requirements (clover), the difference in sorption between the $<2 \mathrm{~mm}$ fraction and whole soils is greater because both factors are contributing to the overall difference. Therefore the decrease in $\mathrm{P}$ rates for clover growth on whole soils occurs at quite a low gravel content and increases exponentially. On the other hand, the lower $\mathrm{P}$ requirements of wheat mean that the gravel content is the only factor contributing to the difference in sorption between the whole soil and the $<2 \mathrm{~mm}$ fraction. Therefore, the 'threshold' gravel content of the soil occurs at a higher value followed by a steep decrease in $\mathrm{P}$ required with further increases in soil gravel content. The exponential responses shown in Fig. 5 are probably because the surface area available for sorption is decreased not only by the increasing amount of gravel but also because the proportion of large gravels increases with the total gravel content. 
In reality, however, $\mathrm{P}$ application rates are estimated from measures of extractable P (Colwell 1963) and not through sorption measures. In a field soil, in which the measure of extractable $P$ obtained from analysis of the $<2 \mathrm{~mm}$ fraction indicates that no biological response to $\mathrm{P}$ will occur, an under-estimation of the $\mathrm{P}$ requirement may result for a soil with a high gravel content because the quantity of extractable $\mathrm{P}$ is small in comparison to a soil with a low gravel content. In other words, the soil test may meet the short term intensity requirements of the plant but may not be able to maintain this intensity because of a lack of quantity.

In conclusion, the results suggest that, when estimating $P$ application rates for lateritic soils by using sorption measures, over-application may result if the $>2 \mathrm{~mm}$ gravel fraction is ignored. The degree of over-application will depend on the particular plant requirement for $\mathrm{P}$, especially at low gravel contents. At high gravel contents, differences in plant requirement are less important than the level of gravel content.

\section{References}

Barrow, N. J. (1980). Differences amongst a wide-ranging collection of soils in the rate of reaction with phosphate. Aust. J. Soil Res. 18, 215-24.

Barrow, N. J. (1982). Soil fertility changes. In 'Phosphorus in Australia'. Eds A. B. Costin and C. H. Williams.) (Centre for Resource and Environment: Canberra.)

Barrow, N. J., and Shaw, T. C (1979). Effects of solution: soil ratio and vigour of shaking on the rate of phosphate adsorption by soil. J. Soil. Sci. 30, 67-76.

Colwell, J. D. (1963). The estimation of phosphorus fertilizer requirements of wheat in southern New South Wales by soil analysis. Aust. J. Exp. Agric. Anim. Husb. 3, 190-7.

Finkl, C. W. (1971). Levels and laterites in south-western Australia. Search 10, 382-3.

Gilkes, R. J., Scholz, G., and Dimmock, G. M. (1973). Lateritic deep weathering of granite. J. Soil Sci. 24, 523-36.

Hanson, W. C.(1950). The photometric determination of phosphorus in fertilizers using the phosphovanadomolybdate complex. J. Sci. Food Agric. 1, 172.

Khasawneh, F. E., Sample, E. C., and Kamprath, E. J. (1980). 'The Role of Phosphorus in Agriculture.' (Am. Soc. Agron.: Madison, Wisconson.)

Mulcahy, M. J. (1960). Laterites and lateritic soils in south-western Australia. J. Soil Sci. 11, $207-25$.

Robson, A. D., and Gilkes, R. J. (1981). Fertilizer responses (N, P, K, S, micronutrients) on lateritic soils in south-western Australia-A review. Int. Sem. on Laterization Processes, UNESCO-IGS, Triv. India.

Taylor, R. M., and Schwertmann, U. (1974). The association of phosphorus with iron in ferruginous concretions. Aust. J. Soil Res. 12, 133-45. 